Gut, 1970, 11, 989-993

\title{
Studies of the effect of metoclopramide and apomorphine on gastric emptying and secretion in man
}

\author{
N. RAMSBOTTOM AND J. N. HUNT \\ From the Department of Physiology, Guy's Hospital Medical School, London SE1
}

SUMMARY With oral and intravenous doses of metoclopramide there was no constant effect on the gastric emptying of test meals of glucose or sodium citrate, nor was secretion of acid by the stomach in response to test meals of glucose or sodium citrate affected. Apomorphine, in subnauseous doses $(0.25 \mathrm{mg}$ intravenously) slowed the gastric emptying of test meals containing sodium citrate, and $10 \mathrm{mg}$ of intravenous metoclopramide abolished the slowing of gastric emptying caused by apomorphine.

There have been two convincing double-blind radiological studies which have shown that metoclopramide increases the rate of gastric emptying in man (Margieson, Sorby, and Williams, 1966; James and Hume, 1968). Metoclopramide is now used to hasten gastric emptying in the radiological assessment of the small bowel (James and Hume, 1968). Few unpleasant and no serious side effects have been noted (Trafford, Fisher, Marshall, and Douthwaite, 1967). As the main site of action of metoclopramide is still uncertain (Eisner, 1968), the following studies were made in man.

There are receptors in the duodenum which slow gastric emptying in response to the osmotic pressure of the luminal contents (Hunt and Pathak, 1960). It occurred to us that one action of metoclopramide might be to interfere with the inhibition of gastric emptying by these receptors. If this were so the gastric emptying of glucose solutions, which stimulate duodenal receptors, would be hastened. On the other hand, the gastric emptying of sodium citrate solutions would remain unchanged since they are a minimal stimulus to the duodenal receptors inhibiting

Received for publication 1 July 1970. gastric emptying (Hunt and Knox, 1962).

In the present paper we describe the studies which we undertook to pursue this idea.

\section{Methods and Technique}

In all these studies the subjects were healthy male medical colleagues. Not more than one experiment on any one subject was performed on one day. Experiments involving apomorphine were separated by intervals of at least one week.

The subjects came to the laboratory in the early morning having fasted since the previous evening. Water was taken between arising and reaching the laboratory if desired. Any secretions in the stomach were washed out with $250 \mathrm{ml}$ of water which was swallowed and immediately recovered through a rubber tube with a $3 \mathrm{~mm}$ bore with seven side holes. The position of the tube was judged from the ease of recovery of the swallowed water. The test meal at $37^{\circ} \mathrm{C}$ was given through the tube in about 75 seconds. The volume of the original meal in the recovered gastric contents was determined from the amount 
of phenol red recovered. The gastric contents were analysed as described by Hunt (1959) and Hunt and Knox (1962). The amount of acid secreted during the test meal was calculated as $\mathrm{ml} / 160 \mathrm{mN} \mathrm{HCl}$, the supposed concentration at which it is secreted by the parietal cells.

\section{SERIES 1}

Two fasting subjects H.T. and R.M. took doses of $0-30 \mathrm{mg}$ metoclopramide as syrup one hour before receiving a standard test meal. Gastric emptying was studied with $750-\mathrm{ml}$ test meals containing $50 \mathrm{~g}$ glucose monohydrate (250 milliosmoles) and $60 \mathrm{mg}$ phenol red per litre. The interval between instilling and recovering the meal was 20 minutes as it was also in the studies with glucose test meals in series 2 and 3 .

\section{SERIES 2}

There were four subjects. The dose range of meto-

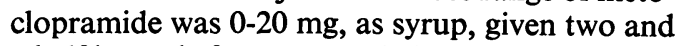
a half hours before test meals ( $50 \mathrm{~g}$ glucose monohydrate, ie, 250 milliosmoles per litre) similar to those used in series 1 .

SERIES 3

Five subjects were given metoclopramide intravenously in the dose range $0-10 \mathrm{mg} 10$ minutes before receiving a test meal $(50 \mathrm{~g}$ glucose monohydrate, ie, 250 milliosmoles per litre) similar to those in series 1 and 2. Isotonic saline was used as a control intravenous injection. The subjects did not know whether they were receiving active or control material.

SERIES 4

This series was a repetition of series 3 using $100 \mathrm{mN}$ sodium citrate (133 milliosmoles per litre) test meals instead of the glucose solution used in series 3 . Because the $100 \mathrm{mN}$ sodium citrate meals leave the stomach much more rapidly than the glucose meals the interval between instilling and recovering the meals was reduced to 10 minutes in series 4 and 5 .

\section{SERIES 5}

In series 1 to 4 metoclopramide did not consistently increase the rate of gastric emptying. In series 5 therefore we slowed gastric emptying with apomorphine in order to provide a situation more favourable for the study of any hastening action which metoclopramide might have.

This series was divided into three parts, and the tests were performed in four subjects. In the first part the rate of gastric emptying of sodium citrate in test meals $(100 \mathrm{mN})$ was measured. In the second part the effect of $0 \cdot 2-0 \cdot 25 \mathrm{mg}$ intravenous apomorphine given 10 minutes before instilling the sodium citrate meals $(100 \mathrm{mN})$ was measured. In the third part the effect of $10 \mathrm{mg} \Omega$ intravenous metoclopramide on the emptying of sodium citrate test meals $(100 \mathrm{mN})$ was measured following previous intravenous injection of apo- $\stackrel{9}{+}$ morphine. The metoclopramide was given five minutes after the apomorphine and five minutes before the test meal.

PRESENTATION OF RESULTS (SERIES 1-4)

As the doses required to produce effects with metoclopramide under our conditions were not known, subjects were given a series of doses of $\vec{\omega}$ increasing magnitude starting with a dummy dose. The results for the zero dose and for sub- $\rightleftharpoons$ threshold doses thus serve as controls for the $\overrightarrow{ }$ doses that were large enough to give effects. The $\overrightarrow{\vec{N}}$ doses were unknown to the subjects. In order to determine the relationship between dose and $\infty$ effect, the measured response, say volume of meal $\frac{9}{工}$ recovered, was plotted on the ordinate against dose on the abscissa. By eye the relationship was $\square$ rectilinear in all instances. Regression lines were $\mathbb{\mathbb { D }}_{\mathbb{R}}$ fitted by least squares with dose as independent variable.

\section{Results}

SERIES 1

Table I shows that for six oral doses varying between 0 and $20 \mathrm{mg}$, R.M. showed a mean

\begin{tabular}{|c|c|c|c|c|c|}
\hline Subject & $n$ & $\begin{array}{l}\text { Intercept } \\
(a)\end{array}$ & $\begin{array}{l}\text { Slope } \\
\text { (b) }\end{array}$ & SE Slope & $\mathbf{P}$ \\
\hline $\begin{array}{l}\text { Series I } \\
\text { H.T. } \\
\text { R.M. }\end{array}$ & $\begin{array}{l}6 \\
5\end{array}$ & $\begin{array}{l}396 \\
373\end{array}$ & $\begin{array}{r}0.80 \\
-4 \cdot 70\end{array}$ & $\begin{array}{l}1 \cdot 09 \\
1 \cdot 29\end{array}$ & $\begin{array}{l}0.5 \\
0.05\end{array}$ \\
\hline $\begin{array}{l}\text { Series } 2 \\
\text { H.T. } \\
\text { K.X. } \\
\text { P.R. } \\
\text { R.M. }\end{array}$ & $\begin{array}{l}5 \\
5 \\
5 \\
5\end{array}$ & $\begin{array}{l}421 \\
295 \\
352 \\
423\end{array}$ & $\begin{array}{r}-0.54 \\
4.14 \\
6.32 \\
-0.54\end{array}$ & $\begin{array}{l}1 \cdot 10 \\
4 \cdot 03 \\
3 \cdot 38 \\
2 \cdot 64\end{array}$ & $\begin{array}{l}0.7 \\
0.35 \\
0.25 \\
0.85\end{array}$ \\
\hline $\begin{array}{l}\text { Series } 3 \\
\text { H.T. } \\
\text { K.X. } \\
\text { M.N. } \\
\text { P.R. } \\
\text { R.M. }\end{array}$ & $\begin{array}{l}5 \\
5 \\
5 \\
5 \\
5\end{array}$ & $\begin{array}{l}445 \\
342 \\
297 \\
427 \\
385\end{array}$ & $\begin{array}{r}-2.44 \\
3.20 \\
-1.64 \\
2.00 \\
-0.44\end{array}$ & $\begin{array}{l}6 \cdot 42 \\
6 \cdot 48 \\
6 \cdot 57 \\
5 \cdot 21 \\
5 \cdot 93\end{array}$ & $\begin{array}{l}0.7 \\
0.7 \\
0.8 \\
0.7 \\
0.9\end{array}$ \\
\hline $\begin{array}{l}\text { Series } 4 \\
\text { H.T. } \\
\text { K.X. } \\
\text { M.N. } \\
\text { P.R. } \\
\text { R.M. }\end{array}$ & $\begin{array}{l}7 \\
7 \\
7 \\
7 \\
7\end{array}$ & $\begin{array}{l}239 \\
238 \\
341 \\
304 \\
262\end{array}$ & $\begin{array}{r}2.57 \\
7.89 \\
-3.42 \\
-6.32 \\
-15.85\end{array}$ & $\begin{array}{r}6.91 \\
6.07 \\
10.49 \\
7.55 \\
3.70\end{array}$ & $\begin{array}{l}0.75 \\
0.25 \\
0.75 \\
0.45 \\
0.01\end{array}$ \\
\hline
\end{tabular}

Table I Volume of meal recovered in series 1-4

The coefficients are for regression equations of volume of test meal recovered $(y \mathrm{ml})$ against dose of metoclopramide $(x \mathrm{mg}$ independent variable): $a$ is the value of the extrapolated regression line at dent variable): $a$ is the value of the extrapolated regression line at
zero dose. The regression equations include values obtained with zero dose: $\boldsymbol{n}$ is the number of tests per subject. The null hypothesis is that the volume of meal recovered is independent of dose of drug. $P$ is obtained by ' $t$ ' test of the slope. 
reduction in volume recovered of $4.7 \mathrm{ml}$ per $\mathrm{mg}$. Thus overall, a $20 \mathrm{mg}$ dose reduced the volume of glucose meal recovered from 373 to $279 \mathrm{ml}$ (373-94), which was significant at the 1 in 20 level. Subject H.T. showed an insignificant increase in volume recovered over the dose range 0-30 mg. Parietal secretion was unchanged by the drug (Table II).

SERIES 2

Table I shows that when the drug was given orally two and a half hours before the test there were no significant increases or decreases in the volume of the meal recovered. In one subject there was a small but statistically significant increase in parietal secretion with dose (Table II).

\section{SERIES 3}

Table I shows that with a glucose test meal and the drug given intravenously there was no significant change in volume of meal recovered. Parietal secretion was unchanged (Table II).

\section{SERIES 4}

Table I shows that using rapidly emptying sodium citrate test meals intravenous metoclopramide gave a highly significant reduction in the volume of meal recovered in R.M.; the volume recovered at 10 minutes falling from $268 \mathrm{ml}$ with zero dose to $104 \mathrm{ml}$ with $10 \mathrm{mg}$ given intravenously. No other subjects showed any change. Parietal secretion was unchanged (Table II).

\begin{tabular}{|c|c|c|c|c|c|}
\hline Subject & $n$ & $\begin{array}{l}\text { Intercept } \\
(a)\end{array}$ & $\begin{array}{l}\text { Slope } \\
\text { (b) }\end{array}$ & SE Slope & $\mathbf{P}$ \\
\hline $\begin{array}{l}\text { Series } 1 \\
\text { H.T. } \\
\text { R.M. }\end{array}$ & $\begin{array}{l}6 \\
5\end{array}$ & $\begin{array}{l}8 \cdot 3 \\
20 \cdot 8\end{array}$ & $\begin{array}{r}0.54 \\
-0.42\end{array}$ & $\begin{array}{l}0.37 \\
0.31\end{array}$ & $\begin{array}{l}0.2 \\
0.3\end{array}$ \\
\hline $\begin{array}{l}\text { Series } 2 \\
\text { H.T. } \\
\text { K.X. } \\
\text { P.R. } \\
\text { R.M. }\end{array}$ & $\begin{array}{l}5 \\
5 \\
5 \\
5\end{array}$ & $\begin{array}{l}15 \cdot 0 \\
17 \cdot 4 \\
29 \cdot 4 \\
28\end{array}$ & $\begin{array}{r}-0.06 \\
0.06 \\
0.52 \\
0.20\end{array}$ & $\begin{array}{l}0.08 \\
0.36 \\
0.09 \\
0.34\end{array}$ & $\begin{array}{l}0.5 \\
0.9 \\
0.01 \\
0.9\end{array}$ \\
\hline $\begin{array}{l}\text { Series } 3 \\
\text { H.T. } \\
\text { K.X. } \\
\text { M.N. } \\
\text { P.R. } \\
\text { R.M. }\end{array}$ & $\begin{array}{l}5 \\
5 \\
5 \\
5 \\
5\end{array}$ & $\begin{array}{l}13 \cdot 8 \\
22.6 \\
18 \cdot 2 \\
31 \cdot 6 \\
23.6\end{array}$ & $\begin{array}{r}-0.40 \\
-0.36 \\
-1.16 \\
0.00 \\
-1.12\end{array}$ & $\begin{array}{l}0.39 \\
0.84 \\
0.73 \\
0.99 \\
0.74\end{array}$ & $\begin{array}{l}0.9 \\
0.7 \\
0.2 \\
0.2\end{array}$ \\
\hline $\begin{array}{l}\text { Series } 4 \\
\text { H.T. } \\
\text { K.X. } \\
\text { M.N. } \\
\text { P.R. } \\
\text { R.M. }\end{array}$ & $\begin{array}{l}7 \\
7 \\
7 \\
7 \\
7\end{array}$ & $\begin{array}{l}11 \cdot 8 \\
10.5 \\
21 \cdot 5 \\
19.8 \\
19.1\end{array}$ & $\begin{array}{r}-0.19 \\
-0.37 \\
-0.31 \\
0.13 \\
0.11\end{array}$ & $\begin{array}{l}0.16 \\
0.19 \\
0.30 \\
0.44 \\
0.55\end{array}$ & $\begin{array}{l}0.3 \\
0.1 \\
0.3 \\
0.3 \\
0.9\end{array}$ \\
\hline
\end{tabular}

Table II Volume of parietal secretion recovered in series $1-4$

The coefficients are for regression equations of volume of parietal secretion recovered $(y \mathrm{ml})$ against dose of metoclopramide $(x \mathrm{mg}$ independent variable): $a$ is the value of the extrapolated regression line at zero dose. The regression equations include values obtained with zero dose: $n$ is the number of tests per subject. The null hypothesis is that the volume of parietal secretion is independent of dose of drug. $P$ is obtained by a ' $t$ ' test of the slope.

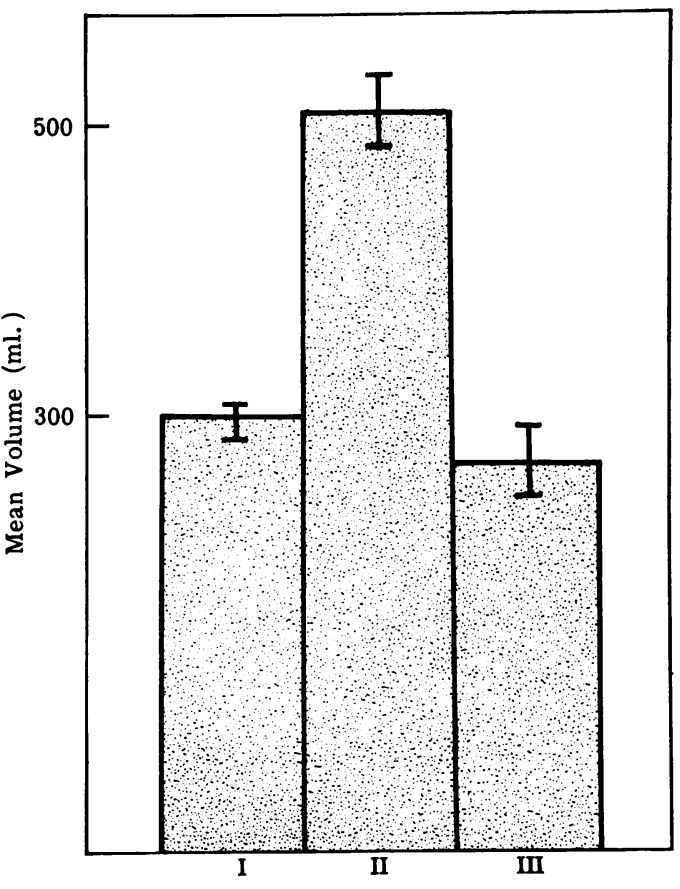

Fig. 1 Mean volume of sodium citrate test meal recovered after 10 minutes in four subjects. I-with sodium citrate alone (control). II-10 minutes after intravenous apomorphine. III-10 minutes after apomorphine and five minutes after metoclopramide. Vertical bars represent the standard error of the mean.

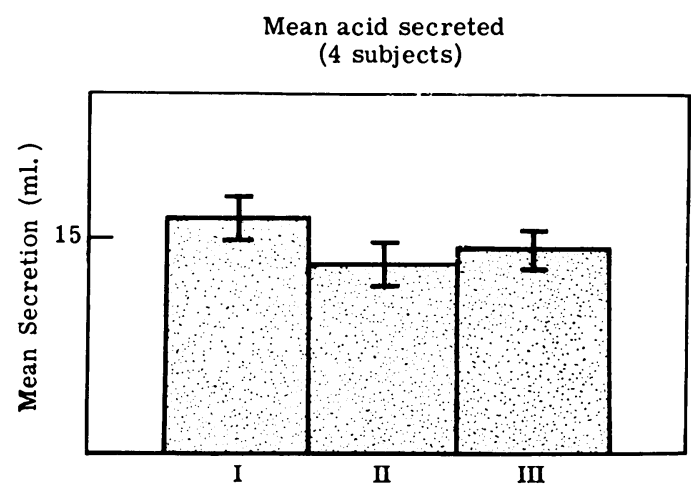

Fig. 2 Mean acid secreted in response to sodium citrate test meals recovered after 10 minutes in four subjects. I-with sodium citrate alone (control). II-10 minutes after intravenous apomorphine. III-10 minutes after apomorphine and five minutes after metoclopramide. Vertical bars represent the standard error of the mean $(\mathrm{ml} 0 \cdot 16 \mathrm{NHCl})$. 


\section{SERIES 5}

The effects of apomorphine on the volume of sodium citrate meal recovered are shown in Figure 1. In the control series, a mean of $299 \mathrm{ml}$ (SE $\pm 17 \cdot 4$ ) of the original meal was recovered. When apomorphine was given 10 minutes before the test meal the mean recovery increased to $509 \mathrm{ml}$ (SE \pm 19.9). When metoclopramide was given five minutes after the apomorphine and five minutes before the test meal, the mean volume recovered was $265 \mathrm{ml}(\mathrm{SE} \pm 26 \cdot 4)$. This volume is not significantly less than the $299 \mathrm{ml}$ obtained for the control citrate test meals in this series (paired ' $t$ ' test). Figure 2 shows that the parietal secretion was little changed after either apomorphine or apomorphine plus metoclopramide. There was no evidence of significant regurgitation of bile in any of the recovered gastric contents.

\section{Discussion}

There is clear evidence from two double-blind radiological trials that metoclopramide in intravenous doses of $10 \mathrm{mg}$ increases the rate of gastric emptying (Margieson et al, 1966; James and Hume, 1968). We expected our test meal techniques to give similar results. Initially test meals containing $50 \mathrm{~g}$ glucose $/ 1$ were used on the assumption that metoclopramide might block the effect of glucose on the duodenal osmoreceptors. In our first series R.M. showed a significant increase in gastric emptying. Because the drug had produced no such effect in H.T. it seemed desirable to have a longer period for absorption of the metoclopramide before giving the glucose test meal. Four subjects therefore took varying doses of syrup 150 minutes before the test. There was evidence of absorption since all the subjects were sleepy after higher doses, but in spite of this, none of the subjects, not even R.M., showed an increase in gastric emptying. At this stage it seemed that we should have used an intravenous form of metoclopramide to ensure that the administered dose was effective at the time of the test. The previous four subjects and M.N. were given doses of metoclopramide intravenously 10 minutes before the test meal of glucose. There was no significant change in gastric emptying. Four out of five subjects became drowsy with the larger doses.

It seemed that in using glucose we had chosen the wrong type of test meal to demonstrate the effect. It occurred to us that metoclopramide might increase gastric emptying by changing glucose metabolism either generally or locally. A fall in blood sugar is a known stimulus of gastric motility (Bachrach, 1953). Alternatively, because glucose slows gastric emptying by stimulating duodenal receptors, metoclopramide might not be able to overcome such an effect. For this reason we now used test meals of sodium citrate solution which have a minimal effect on the duodenal osmoreceptors slowing gastric emptying $\overrightarrow{\vec{F}}$ (Hunt and Knox, 1962). With these citrate meals $\overrightarrow{0}$ only one subject (R.M.) out of five showed a $\overline{0}$ significant increase in gastric emptying. In $\frac{\bar{\omega}}{2}$ summary only two out of 16 studies (Table $I$ ) in $\mathbb{D}$ five subjects showed any consistent increase in gastric emptying with increase in dose of meto- $\frac{1}{2}$ clopramide.

At this point it seemed that the barium sulphate $\vec{\overrightarrow{ }}$ in the previous radiological studies might be $\stackrel{\omega}{\mathcal{O}}$ the critical factor but a few experiments with barium in the laboratory established that the gastric emptying of barium sulphate suspensions. was similar to that of water (to be published). $\vec{N}$ From casual observations on H.T., it was known $\varphi_{\odot}$ that gastric emptying in the $x$-ray room could on $\bullet$

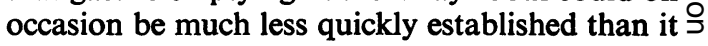
was in the laboratory. It occurred to us that patients having barium meals are under some $\mathbb{\Phi}_{\overparen{D}}$

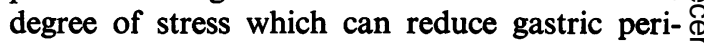
stalsis (Jungmann and Venning, 1955). It seemed $\bar{\sigma}$ possible that metoclopramide might only increase $\stackrel{\Phi}{-}$ the rate of gastric emptying when it was already $\vec{\varphi}$ reduced by central nervous action. We therefore wished to test the effect of metoclopramide during slowed gastric emptying. Having shown that apomorphine slowed gastric emptying we had a model in which to study the effect of metoclopramide. Ten milligrams of metoclopramide $\frac{\circ}{\odot}$ abolished the very considerable slowing of gastric $\stackrel{\circ}{\Rightarrow}$ emptying produced by $0 \cdot 2-0 \cdot 25 \mathrm{mg}$ apomorphine, the molar ratio being about 50:1.

The doses of apomorphine used produced either no nausea or only very transient nausea. Thus at the time apomorphine was slowing gastric $\stackrel{\odot}{\rightleftharpoons}$ emptying, presumably by acting on the area postrema (Borison and Wang, 1953), it was 3 causing no other signs or symptoms. This raises $\dot{\delta}$ the question as to whether gastric emptying may be slowed by naturally occurring substances, say $ᄋ$ adrenaline, in the circulation acting on the area postrema.

This investigation is an interesting example of the difficulties which may arise in replicating in $\%$ the laboratory results obtained in clinical work. $N$ The unstressed state of our healthy trained $\underset{\mathrm{N}}{\mathcal{N}}$ subjects was apparently responsible for the ineffectiveness of metoclopramide in hastening 0

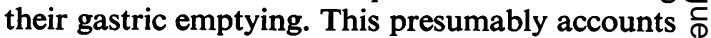
for the difference between our results and the $\stackrel{\oplus}{?}$ proven effectiveness of metoclopramide in clinical circumstances.

We are grateful to Beecham Research Laboratories for supplies of metoclopramide (Maxolon) and for support. 


\section{References}

Bachrach, W. H. (1953). Action of insulin hypoglycemia on motor and secretory functions of the digestive tract. Physiol. Rev., $33,566-592$.

Borison, H. L., and Wang, S. C. (1953). Physiology and pharmacology of vomiting. Pharmacol. Rev., 5, 193-230.

Eisner, M. (1968). Gastrointestinal effects of metoclopramide in man. In vitro experiments with human smooth muscle preparations. Brit. med. J., 4, 679-680.

Hunt, J. N. (1959). Gastric emptying and secretion in man. Physiol. Rev., 39, 491-533.

Hunt, J. N., and Knox, M. T. (1962). The regulation of gastric emptying of meals containing citric acid and salts of citric acid. J. Physiol., 163, 34-45.
Hunt, J. N., and Pathak, J. D. (1960). The osmotic effects of some simple molecules and ions on gastric emptying. J. Physiol., 154, 254-269.

James, W. B., and Hume, R. (1968). Action of metoclopramide on gastric emptying and small bowel transit time. Gut, 9, 203-205.

Jungmann, H., and Venning, P. (1955). Radiological observations of stomach changes accompanying threat of injection in a sample of peptic ulcer patients. Psychosom. Med., 17, 57-61.

Margieson, G. R., Sorby, W. A., and Williams, H. B. L. (1966). The action of metoclopramide on gastric emptying: a radiological assessment. Med. J. Aust., 2, 1272-1274.

Trafford, J. A. P., Fisher, A. M. H., Marshall, S., and Douthwaite A. H. (1967). Metoclopramide (Maxolon)-A new antiemetic. Brit. J. clin. Pract., 21, 457-460.

(2) 